\title{
Biology of sea turtles under risk from tiger sharks at a foraging ground
}

\author{
Michael R. Heithaus ${ }^{1, *}$, Alejandro Frid ${ }^{2}$, Aaron J. Wirsing ${ }^{2}$, Lars Bejder ${ }^{3}$, \\ Lawrence M. Dill ${ }^{2}$ \\ ${ }^{1}$ Department of Biological Sciences, Marine Biology Program, Florida International University, \\ Biscayne Bay Campus ACI 371, 3000 NE 151 Street, North Miami, Florida 33181, USA \\ ${ }^{2}$ Behavioural Ecology Research Group, Department of Biological Sciences, Simon Fraser University, 8888 University Way, \\ Burnaby, British Columbia V5A 1S6, Canada \\ ${ }^{3}$ Department of Biology, Dalhousie University, Halifax, Nova Scotia B3H 4R2, Canada
}

\begin{abstract}
It is important to understand the population structure and space use of sea turtles because of their potential effects on the dynamics of nearshore ecosystems. Much of our current understanding is skewed because the ecology of sea turtles on their foraging grounds is known best from areas where there are, or have been, major human impacts. We studied green Chelonia mydas and loggerhead Caretta caretta sea turtles on the relatively pristine feeding ground of Shark Bay, Western Australia, where tiger sharks Galeocerdo cuvier are a major mortality agent. Recapture rates were lower for green than for loggerhead turtles, possibly reflecting a larger population rather than low site fidelity for greens. The sex ratio of loggerhead turtles was not significantly different from 1:1, whereas green turtles showed a strong female bias. Size distributions of both species were skewed towards larger (and presumably older) individuals relative to a human-impacted feeding ground in eastern Australia. Body condition varied temporally for green turtles, but not for loggerhead turtles, possibly due to longer distances traveled to nesting beaches by green turtles. Rates of shark-inflicted injuries were higher for loggerhead turtles, especially males, than for greens. Sublethal effects of these injuries were not evident. There are notable differences between sea turtles threatened primarily by tiger sharks in Shark Bay and populations on feeding grounds where historical and current mortality causes are anthropogenic. We conclude that without baseline data from relatively pristine habitats our understanding of human impacts on sea turtle populations suffers from a limited scope.
\end{abstract}

KEY WORDS: Sea turtle $\cdot$ Tiger shark $\cdot$ Predation risk $\cdot$ Population structure $\cdot$ Shifting baseline $\cdot$ Site fidelity

\section{INTRODUCTION}

It is important to understand the population structure and space use of sea turtles because of their potential effects on the dynamics of nearshore marine ecosystems. Green turtles Chelonia mydas are important grazers in a number of seagrass communities throughout the tropics and subtopics, where they play a role in detrital cycles and affect the growth patterns of seagrass (Thayer et al. 1982, Bjorndal 1997, Bjorndal et al. 2000, Aragones 2000, Aragones \& Marsh 2000, Bjorn- dal \& Jackson 2003). Although their role in marine ecosystems is poorly known, loggerhead turtles Caretta caretta may influence benthic communities through trophic interactions or benthic disturbance (e.g. Bjorndal 2003).

Adult males and females of both species migrate from breeding and nesting areas - where turtle biology is best known - to sometimes distant nearshore foraging grounds. Studies on these foraging grounds are important for understanding how turtles influence the structure of nearshore systems, as well as the 
growth and mortality factors that affect demography. For example, mortality on feeding grounds appears to be responsible for the decline of nesting populations of loggerhead turtles along the coast of Queensland in eastern Australia (Limpus et al. 1994b), and humaninflicted mortality of green turtles on feeding grounds in the Caribbean appears to have major consequences for population stability and growth (Bjorndal et al. 2003). Not all threats to sea turtles on foraging grounds are anthropogenic, and both green and loggerhead turtles may be at risk of predation from large sharks, particularly the tiger shark Galeocerdo cuvier (e.g. Heithaus et al. 2002a). The intensity of this risk varies geographically (e.g. Limpus et al. 1994a,b, Heithaus et al. 2002a, Limpus \& Limpus 2003), and little is known about predation rates on adult sea turtles at feeding grounds or about the influence of predators on the behavior and reproduction of these animals (but see Jessop et al. 2003).

To date, the ecology of turtles on foraging grounds is best known where humans have harvested turtles extensively or have degraded their habitats (Jackson 1997). These areas include the southern Great Barrier Reef and Moreton Bay, NE Australia (e.g. Limpus et al. 1994a,b, Limpus \& Limpus 2003), and the Caribbean (e.g. Bjorndal 1980, Bjorndal et al. 2000). Because of human-induced declines in large shark populations (e.g. Baum et al. 2003, Baum \& Meyers 2004), it is possible that humans have replaced sharks as the primary predator in these areas. Given the life-history characteristics of sea turtles (e.g. slow growth, delayed maturation, long lifespan), anthropogenic effects at disturbed foraging grounds might continue long after harvesting of turtles stops or diminishes. Further, even if turtles are not targeted, fisheries bycatch or disease might be important mortality agents at foraging grounds near human populations (e.g. George 1997, Lewison et al. 2004).

In contrast, Shark Bay, Western Australia, is a large and relatively undisturbed foraging ground, containing large populations of green and loggerhead turtles, as well as of tiger sharks (Heithaus 2001). Historical harvest rates have been mild, and nesting occurs along the relatively unpopulated central and northern Western Australian coastline (e.g. Baldwin et al. 2003). In Shark Bay, large sharks - rather than humans-are the primary source of predation and injury (e.g. Limpus et al. 1994a,b, Heithaus et al. 2002a).

This paper describes the biology of green and loggerhead sea turtles in Shark Bay and assesses whether the shifting baseline syndrome (sensu Pauly 1995) has influenced our perception of turtles on foraging grounds. We quantify population parameters and use of space by turtles in Shark Bay, and compare our data to those from human-exploited populations.

\section{MATERIALS AND METHODS}

Study site. This study was conducted in the Eastern Gulf of Shark Bay, offshore of the Monkey Mia Dolphin Resort (ca. $25^{\circ} 45^{\prime} \mathrm{S}, 113^{\circ} 44^{\prime} \mathrm{E}$ ). Shark Bay is a large, semi-enclosed bay, approximately $800 \mathrm{~km}$ north of Perth, Western Australia (see Heithaus 2001). The Eastern Gulf is relatively shallow, with nearshore shallows covered largely by sand, with some seagrass patches. There are numerous shallow banks offshore that are covered primarily by the seagrass Amphibolis antarctica $(<4.0 \mathrm{~m}$ depth) and surrounded by relatively deeper waters (6.5 to $15.0 \mathrm{~m}$ ). Shark Bay contains the largest reported seagrass beds in the world (Walker 1989), a feature that contributed to its listing as a World Heritage Area in 1991. Expansive seagrass beds and abundant invertebrates support large populations of green and loggerhead turtles. Neither species is known to nest in the Eastern Gulf. Green turtles feeding in Shark Bay are believed to nest along the NW coast of Australia, while the loggerhead turtles may nest in similar geographic regions or on Dirk Hartog Island and other barrier islands in the Western Gulf of Shark Bay (Baldwin et al. 2003).

Study methods. We searched haphazardly for turtles in shallow areas (usually $<5 \mathrm{~m}$ ) and, to a lesser extent, in areas $\sim 10 \mathrm{~m}$ deep, where turtle densities are known to be highest. Turtles were captured by hand (Heithaus et al. 2002a), brought alongside the boat and restrained by the fore-flippers; occasionally, turtles were brought aboard the vessel for attachment of animal-borne cameras (Heithaus et al. 2002c). We recorded the following behaviors at the time of sighting. Surfacing included turtles floating at the surface with their carapace or head above the water line. Swimming turtles were moving below the surface (excluding animals swimming away from the capture boat). Feeding included turtles excavating the sea floor (for loggerhead turtles), consuming seagrass (for green turtles), or captured with food in their mouth. Resting turtles lay motionless on the bottom. Our data likely underestimate the number of feeding turtles, as misclassification into the 'resting' category no doubt occurred to some extent.

Following capture we measured curved carapace length $(\mathrm{CCL})$ and tail length (to the nearest $0.5 \mathrm{~cm}$ ). Titanium tags (Stockbrands), provided by the Department of Conservation and Land Management, Western Australian Marine Turtle Project, were attached to the fore-flippers. From 2000 to 2003 we recorded a qualitative condition index based on the ventral characteristics of the turtle. Turtles were considered to be in poor condition when their undersides were extremely concave; ventral concavity was often accompanied by sunken eyes, extremely bad breath, 
and lethargy during capture and handling. Turtles in fair condition had concave or slightly concave undersides, but were usually active during capture, and other body parts were not obviously in deteriorating condition. Turtles in good condition had flat undersides, and turtles in very good condition had convex undersides.

Determining the sex of turtles in the field from external characteristics is impossible for small turtles and sometimes difficult for large turtles (Limpus et al. $1994 a, b)$. We classified individuals with tail lengths of $>25 \mathrm{~cm}$ as males and all others, which would include some juvenile males, as unclassed (Limpus et al. 1994a,b). We considered individuals with short tails and CCL $>100 \mathrm{~cm}$ to be probable females, since most males should have matured and grown long tails by this size (e.g. Limpus \& Limpus 1994a,b, 2003), and individuals with short tails and CCL $>95 \mathrm{~cm}$ were considered likely females. The likely females category includes all individuals in the probable females category.

Turtles were inspected for shark-inflicted wounds using the criteria of Heithaus et al. (2002a). We considered a wound to be inflicted by a shark when (1) large, crescent-shaped chunks were removed from the carapace that could only have been caused by a shark; (2) at least one-third of a flipper was amputated; or (3) shark tooth impressions were found on the carapace. We did not consider the removal of small portions of the carapace, the removal of distal portions of flippers, or holes in the carapace or flippers to be caused by sharks. In addition to shark wounds, we recorded other injuries (e.g. from boats or other turtles), as well as green turtle fibropapilloma tumors (e.g. George 1997).

Analyses. Because many individuals were recaptured, for some analyses we used only the first capture of the individual, or a single mean value per individual, to avoid pseudoreplication. Size distributions and sex ratios included only the first capture of an individual, as did analyses of sharkinflicted wounds. Wound analyses also excluded turtles $<65 \mathrm{~cm} \mathrm{CCL}$. For analyses of trends in condition, we included the first capture for each individual within a year. Analyses of substratum selection and activity included all captures of all individuals.

For substratum- and depth-selection analyses, turtles were placed into 1 of 3 size categories: small $(<60 \mathrm{~cm} \mathrm{CCL})$, medium (60 to $90 \mathrm{~cm} \mathrm{CCL})$, or large (>90 cm CCL). Analyses of activity excluded feeding, since there were very few occurrences of this behavioral state. Analyses of depth selection were also conducted treating both depth and size as con- tinuous variables. Results were identical to those obtained for size categories.

Species and sex differences in the time and distance moved between recaptures and the probability of having a shark-inflicted wound were investigated using ANOVA. Data were square-root (time between recaptures) or $\log (x+1)$ (distances moved) transformed, and all nonsignificant interactions $(\mathrm{p}<0.10)$ were removed from analyses. Distances were determined using a Geographic Information System (MapInfo).

\section{RESULTS}

\section{Population characteristics}

The total number of individuals caught was 1.4 times greater for green (Chelonia mydas) (328 captures of 304 individuals) than for loggerhead (Caretta caretta) (330 captures of 223 individuals) turtles, despite similar total captures, because loggerheads were more frequently recaptured (see below). The green turtle sex ratio was significantly biased towards probable (3.1:1; $\left.\chi^{2}=31.0, \mathrm{df}=1, \mathrm{p}<0.0001\right)$ or likely females $\left(3.2: 1 ; \chi^{2}=\right.$ $23.8, \mathrm{df}=1, \mathrm{p}<0.0001$ ). For loggerhead turtles, the sex ratio was slightly female-biased, but did not deviate significantly from 1:1 (>95 cm CCL, $\chi^{2}=3.6, \mathrm{df}=1, \mathrm{p}=$ $0.07 ;>100 \mathrm{~cm} \mathrm{CCL}, \chi^{2}=3.0, \mathrm{df}=1, \mathrm{p}=0.08$ ) (Table 1).

Unclassed green turtles ranged from 40.0 to $120.0 \mathrm{~cm}$ $\mathrm{CCL}$, and males, between 89.0 and $118.0 \mathrm{~cm}$ (Fig. 1). Loggerhead turtles ranged from 67.0 to $111.0 \mathrm{~cm} \mathrm{CCL}$ for unclassed turtles and from 88.0 to $112.0 \mathrm{~cm} \mathrm{CCL}$ for male turtles (Fig. 1).

There were species and sex-class effects on recapture rates. Only 14 of $270(5.2 \%)$ unclassed green turtles were recaptured. Male green turtles were recaptured at a significantly higher rate, with 7 of 34 male turtles $(20.6 \%)$ recaptured $\left(\chi^{2}=11.1, \mathrm{df}=1, \mathrm{p}<\right.$

Table 1. Chelonia mydas and Caretta caretta. Comparison of green and loggerhead turtles on the Shark Bay foraging ground. CCL: curved carapace length

\begin{tabular}{|lcc|}
\hline \multirow{2}{*}{ Factor } & \multicolumn{2}{c|}{ Species } \\
& Green & Loggerhead \\
\hline CCL $(\mathrm{cm})(\bar{x} \pm \mathrm{SD})$ & $85.8 \pm 19.2$ & $89.7 \pm 11.0$ \\
Unclassed:male $(>95 \mathrm{~cm})$ & $3.1: 1$ & $1.6: 1$ \\
Unclassed:male $(>100 \mathrm{~cm})$ & $3.2: 1$ & $1.2: 1$ \\
Percent shark injured (male, unclassed) & $3.0,6.5$ & $51.7,27.8$ \\
Percent anthropogenic injuries & 0.0 & 0.0 \\
Percent sighted at surface & 3.4 & 15.4 \\
Percent with tumors & 2.6 & 0.0 \\
Percent recaptured (male, unclassed) & $20.6,5.2$ & $38.7,24.7$ \\
Kilometers between captures $(\bar{x} \pm \mathrm{SD})$ & $0.6 \pm 0.7$ & $2.4 \pm 3.3$ \\
Days between captures $(\bar{x} \pm \mathrm{SD})$ & $152 \pm 158$ & $468 \pm 449$ \\
& \multicolumn{2}{|c}{} \\
\hline
\end{tabular}


0.001); 1 male and 2 unclassed turtles were recaptured twice.

Loggerhead turtles were recaptured significantly more often than were green turtles $\left(\chi^{2}=44.8, \mathrm{df}=1\right.$, $\mathrm{p}<0.001$ ), and male loggerheads (24 of $62 ; 38.7 \%$ ) were recaptured significantly more often than unclassed ones ( 40 of $162 ; 24.7 \%)\left(\chi^{2}=4.3, \mathrm{df}=1, \mathrm{p}<\right.$ $0.05)$. Loggerhead turtles of both sexes were recaptured an average of 1.7 times after the initial capture. However, several individuals were recaptured within the study area $>5$ times (max. $=7$ recaptures).
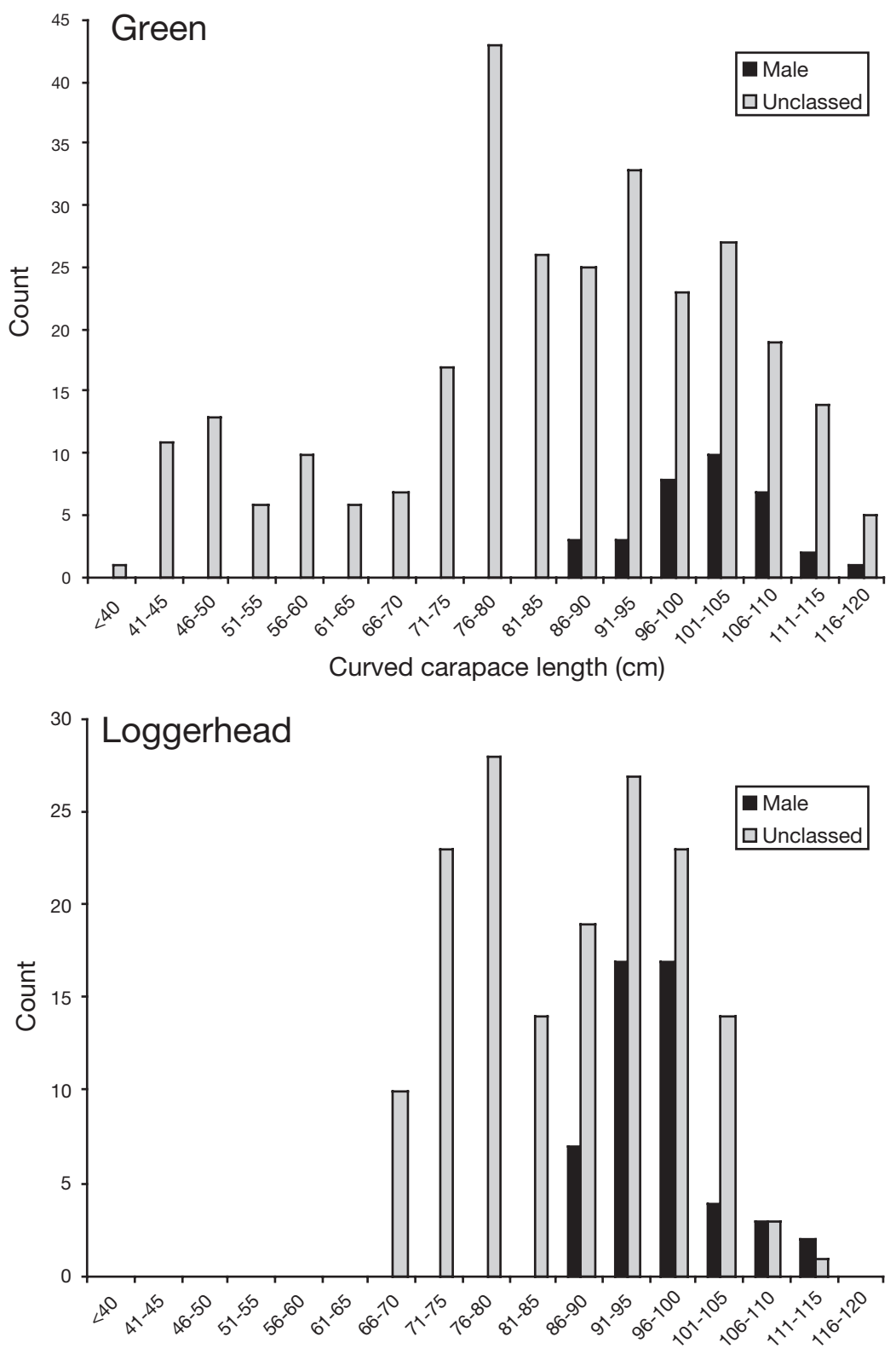

Curved carapace length $(\mathrm{cm})$

Fig. 1. Chelonia mydas and Caretta caretta. Size distribution of green and loggerhead turtles

\section{Use of space and activity}

Time between first and last captures for loggerhead turtles ranged from 2 to $1433 \mathrm{~d}(\overline{\mathrm{X}} \pm \mathrm{SD}=468 \pm 449 \mathrm{~d})$, which was significantly longer than that for green turtles, which ranged from 8 to $406 \mathrm{~d}(\bar{x} \pm \mathrm{SD}=152 \pm 158$; $\left.F_{1,82}=9.7, \mathrm{df}=1, \mathrm{p}<0.003\right)$. There was no effect of sex on total time between captures $\left(F_{1,82}=1.5, \mathrm{df}=1, \mathrm{p}=\right.$ 0.22).

Recaptured green turtles had moved between $100 \mathrm{~m}$ and $2.7 \mathrm{~km}$ (Fig. 2) from their previous capture location. Most movements were within the area of initial capture, and only 1 turtle moved to a neighboring seagrass bank. Loggerhead turtles were recaptured between $50 \mathrm{~m}$ and $15.4 \mathrm{~km}$ from their previous capture site (Fig. 2). The majority of recaptures were within the same general location as the initial capture, but longdistance movements were recorded among offshore seagrass banks and from offshore banks and deep areas to nearshore sand habitats, with 15 of 64 $(23.4 \%)$ animals making at least 1 move outside of their initial capture location (i.e. to another offshore bank). Many loggerhead turtles moved long distances along nearshore shallow habitats. Our data are not adequate to address movements of turtles within deep habitats of the study area.

Average distance between individual recaptures differed between species. Loggerhead turtles moved further than green turtles $(\bar{x} \pm \mathrm{SD}=2.3 \pm 3.3 \mathrm{~km}$ and $0.6 \pm$ $0.6 \mathrm{~km}$, respectively; $F_{1,117}=7.0, \mathrm{p}=$ $0.009)$. There were no sex-class differences for either species $\left(F_{1,117}=0.3, \mathrm{p}=\right.$ 0.56). Similarly, the average distance between recaptures of individual loggerhead turtles was greater than that of green turtles $(\bar{x} \pm \mathrm{SD}=2.4 \pm 3.2 \mathrm{~km}$ and $0.6 \pm 0.7 \mathrm{~km}$, respectively; $F_{1,84}=9.7, \mathrm{p}=$ $0.003)$, and there were no effects of sex class $\left(F_{1,84}=0.05, \mathrm{p}=0.83\right)$. Time between first and last capture $\left(F_{1,84}=0.4, \mathrm{p}=0.54\right)$, time between consecutive recaptures $\left(F_{1,117}=0.061, \mathrm{p}=0.81\right)$, number of recaptures $\left(F_{1,84}=0.02, \mathrm{p}=0.88\right)$ and location of initial capture $\left(F_{1,117}=0.83, \mathrm{p}=0.61\right) \mathrm{did}$ not influence the distances traveled between captures.

Small green turtles were captured in shallower waters $(\bar{X} \pm \mathrm{SD}=1.3 \pm 0.7 \mathrm{~m}$ deep, $\mathrm{n}=41)$ than medium $(\bar{X} \pm \mathrm{SD}=2.1$ 


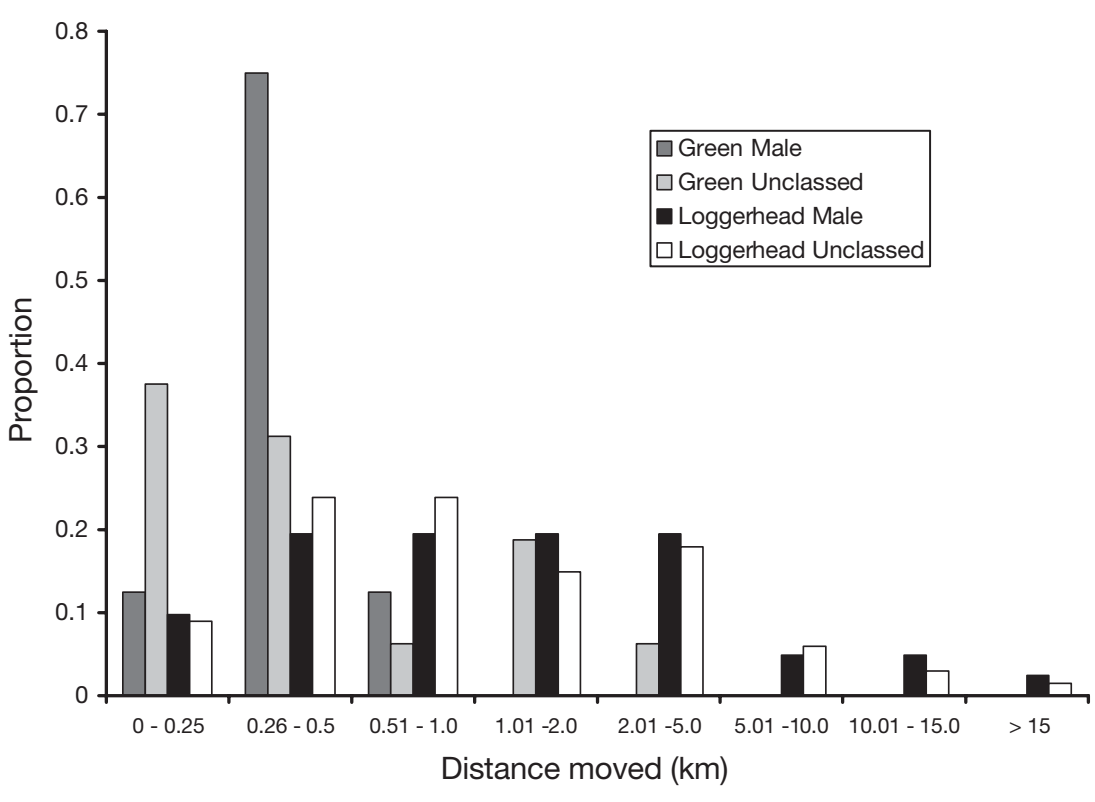

Fig. 2. Chelonia mydas and Caretta caretta. Distance between first and last capture for all turtles recaptured within the study area

\section{Body condition, shark-inflicted injuries and disease}

The body condition of green turtles varied temporally. A greater proportion of turtles was in fair and poor condition in winter months (June and July; $\chi^{2}=29.1$, df $=18, \mathrm{p}<0.05$, Fig. 3). There was no significant temporal variation in the relative body condition of loggerhead turtles that were captured $\left(\chi^{2}=20.5, \mathrm{df}=15\right.$, $\mathrm{p}=0.15)$. Overall, $3.1 \%$ of loggerhead turtles were in poor condition, $24.8 \%$ in fair condition, $35.1 \%$ in good condition and $36.9 \%$ in very good condition. There was no difference in the condition of turtles with and without shark-inflicted damage for either green $\left(\chi^{2}=5.2\right.$, df $=3, \mathrm{p}=$ $0.16)$ or loggerhead $\left(\chi^{2}=1.0, \mathrm{df}=3\right.$, $\mathrm{p}=0.80$ ) turtles. Likewise, there was no difference in body condition between males and females of either $\pm 1.0 \mathrm{~m}$ deep, $\mathrm{n}=131)$ or large $(\bar{x} \pm \mathrm{SD}=2.1 \pm 1.0 \mathrm{~m}$ deep, $\mathrm{n}=153)$ green turtles $\left(F_{2,313}=9.01, \mathrm{p}=0.0002\right)$. Larger green turtles were often captured in moderately deep areas of banks (3 to $5 \mathrm{~m}$ deep) and along bank edges, while the smallest size classes of green turtles tended to be captured in very shallow waters ( 0.5 to $1.5 \mathrm{~m}$ deep) near shore and in areas lined by mangroves. The shift in capture depths of green turtles correlates with a shift in the substratum over which turtles were found. Small turtles were captured over sand bottoms $75 \%$ of the time, which was significantly more often than medium and large green turtles (33 and $34.5 \%$ of captures over sand, respectively); the latter size groups were most often captured over seagrass $\left(\chi^{2}=28.6, \mathrm{df}=2, \mathrm{p}<0.0001\right)$. There were no differences in the capture depths $(t=$ $1.5, \mathrm{df}=304, \mathrm{p}=0.13$ ) or the proportion of turtles captured over sand $\left(\chi^{2}=3.1, \mathrm{df}=2, \mathrm{p}=0.08\right)$ of medium (n $=131, \bar{x} \pm \mathrm{SD}=2.2 \pm 1.9 \mathrm{~m} ; 63 \%$ over sand) or large $(\mathrm{n}=188, \bar{x} \pm \mathrm{SD}=1.9 \pm 1.2 \mathrm{~m} ; 73 \%$ over sand $)$ loggerhead turtles.

Activity at the time of sighting differed between species $\left(\chi^{2}=31.0, \mathrm{df}=3, \mathrm{p}<0.001\right)$. Notably, $\mathrm{a}$ greater proportion of loggerhead turtles $(18 \%)$ than green turtles ( $3 \%$ ) was observed at the surface and a greater proportion of green turtles $(47 \%)$ than loggerhead turtles $(30 \%)$ was seen swimming. Very few green or loggerhead turtles were observed feeding ( $1 \%$ for both species), while turtles frequently were observed stationary on the bottom (49 and 51\%, respectively). species (green turtles: $\chi^{2}=1.9, \mathrm{df}=3, \mathrm{p}=0.58$; loggerhead turtles: $\chi^{2}=1.3, \mathrm{df}=3, \mathrm{p}=0.72$ ).

Shark-inflicted injuries were much more common on loggerhead turtles than green turtles (Table 2, Fig. 4). While there was not a substantial difference

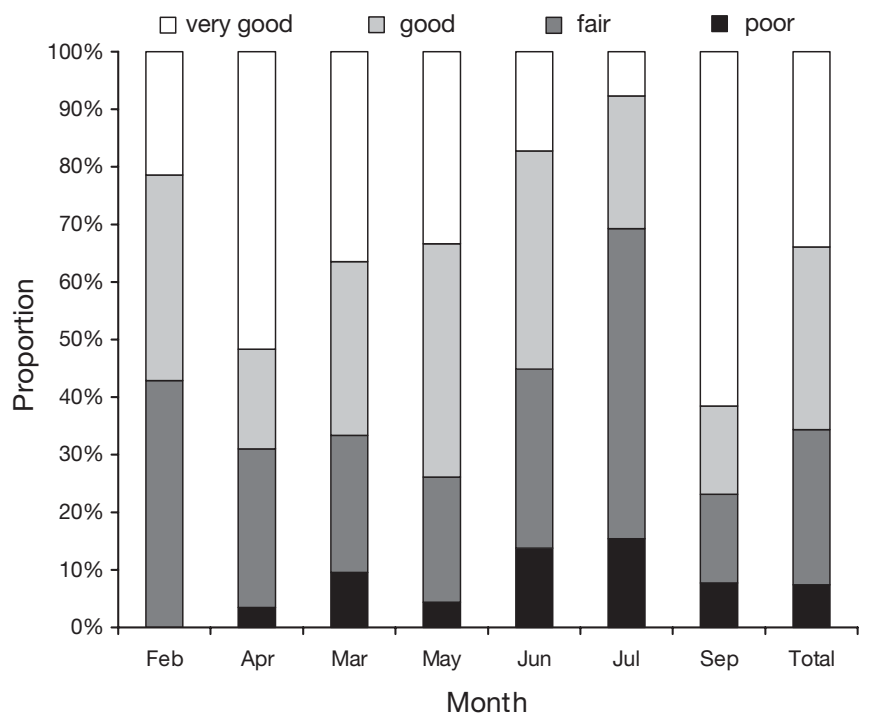

Fig 3. Chelonia mydas. Monthly variation in body condition of green turtles. Analysis only includes months with $>15$ records of body condition 
Table 2. Chelonia mydas and Caretta caretta. Wald $\chi^{2}$ values for analyses of shark-inflicted wounds on green and loggerhead turtles. The presence or absence of a wound was treated as a nominal variable. CCL: curved carapace length

\begin{tabular}{|c|c|c|c|c|c|c|c|c|c|}
\hline & \multicolumn{3}{|c|}{ All } & \multicolumn{3}{|c|}{$>95 \mathrm{~cm} \mathrm{CCL}$} & \multicolumn{3}{|c|}{$>100 \mathrm{~cm} \mathrm{CCL}$} \\
\hline & $\mathrm{df}$ & $\chi^{2}$ & $\mathrm{p}$ & df & $\chi^{2}$ & $\mathrm{p}$ & df & $\chi^{2}$ & $\mathrm{p}$ \\
\hline Species & 1,434 & 4.75 & 0.03 & 1,199 & 17.2 & $<0.0001$ & 1,137 & 11.6 & 0.0006 \\
\hline Sex & 1,434 & 20.8 & $<0.0001$ & 1,199 & 4.66 & 0.030 & 1,137 & 5.5 & 0.02 \\
\hline Species $\times$ Sex & 1,434 & 0.3 & 0.60 & 1,199 & $2.2^{\mathrm{a}}$ & $0.14^{\mathrm{a}}$ & 1,137 & $1.5^{\mathrm{a}}$ & $0.23^{\mathrm{a}}$ \\
\hline
\end{tabular}

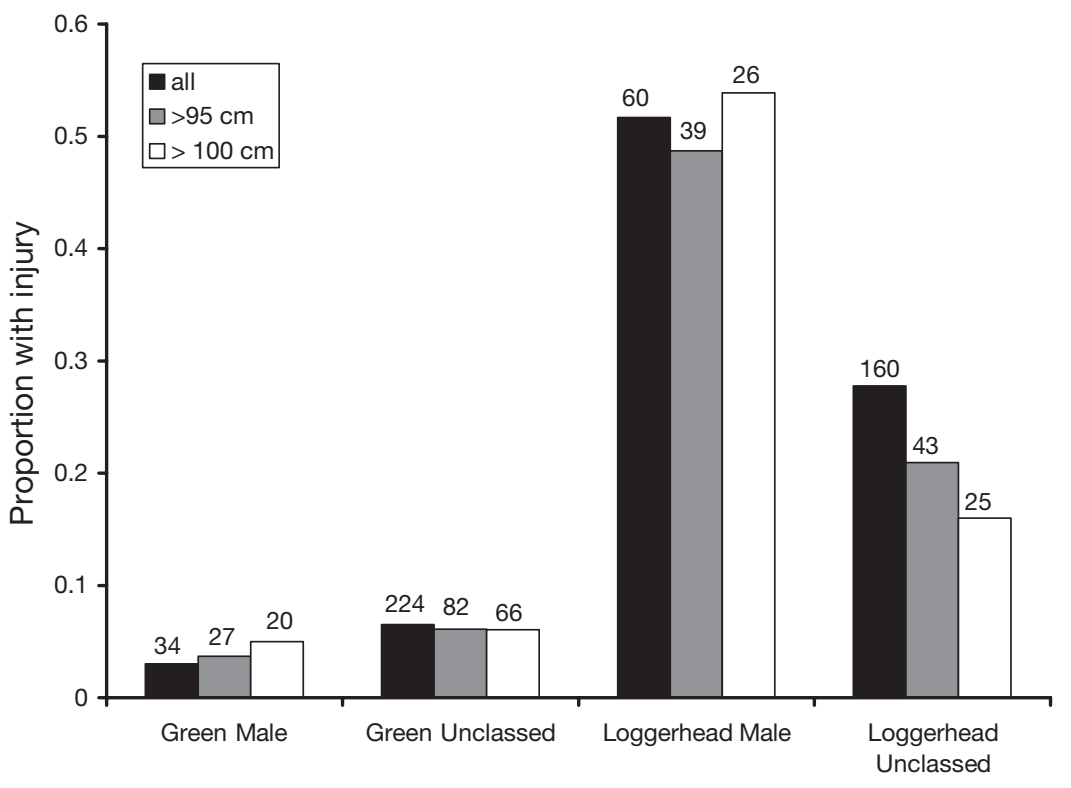

Fig. 4. Chelonia mydas and Caretta caretta. Proportion of turtles bearing shark-inflicted injuries. Sample sizes are above bars

\section{DISCUSSION}

Detailed studies exist for green Chelonia mydas and loggerhead Caretta caretta turtle populations on foraging grounds along the eastern coast of Australia, where human impacts are substantial (Limpus et al. 1994a,b, Limpus \& Limpus 2003). In contrast, the turtle populations we studied in Shark Bay live in a relatively pristine environment that has seen little human-inflicted mortality.

Female green turtles were much more common than males in Shark Bay $(72 \%$ female), a trend seen also at Moreton Bay (65\% female) (Limpus et al. 1994a). The sex ratio of loggerhead turtles in Shark Bay was not significantly different from 1:1. In contrast, male-biased sex ratios have been found in populations of loggerhead turtles in eastern Australia, including feeding grounds of the southern Great Barrier Reef (71\% male) and Moreton Bay (65\%). In these locations, sex was determined

between male and unclassed green turtles, male loggerhead turtles were injured significantly more often than were unclassed loggerheads. The proportion of shark-injured turtles that were recaptured was not significantly different from that of non-injured turtles based on sex and species categories $\left(\chi^{2}=4.2\right.$, df $=3$, $\mathrm{p}=0.24$ ).

Injuries not inflicted by sharks were rare on both green $(\mathrm{n}=3$ ) and loggerhead turtles ( $\mathrm{n}=11)$; none could be attributed definitively to anthropogenic factors. These injuries included missing eyes, holes in fore- and hind-flippers, chips out of the carapace and chunks removed from flippers that may have been inflicted by other turtles.

No loggerhead turtles exhibited fibropapilloma tumors, and only 8 of 304 (2.6\%) green turtles had tumors. Of these, 2 had small tumors on their flippers and another had extremely small tumors in the shoulder area. through gonad observations (Limpus et al. 1994b, Limpus \& Limpus 2003). Our data used tail-length as the sex-class criterion, and thus likely underestimates the proportion of males (Limpus et al. 1994b), but due to the slight female bias in the sex ratio, a deviation from $1: 1$ is unlikely.

Female-biased sex ratios of green turtles on feeding grounds may be caused by the different proportions of the male and female populations involved in breeding migrations. Remigration intervals appear to be shorter for males (Limpus 1993), so it is likely that a greater proportion of males migrates to breeding sites in a particular year. Remigration intervals of male loggerheads are not well known, so it is unclear whether sexspecific remigration rates influence interspecific differences in sex ratio at feeding grounds. In spite of methodological issues, it is possible that the difference in sex ratios of loggerhead turtles between Shark Bay and eastern Australia is real, and is due to differences 
in mortality patterns. There do not appear to be sex differences in adult or immature survival rates of either species in eastern Australia's southern Great Barrier Reef region (Chaloupka \& Limpus 1998, 2002). In Shark Bay, male loggerhead turtles are wounded by tiger sharks more often than females. If this is correlated with higher death rates, then a lower proportion of males in Shark Bay is not surprising.

The size of the smallest loggerhead and green turtles that we captured in Shark Bay were similar to those that had recently settled in Moreton Bay, which is a warm temperate foraging ground (Limpus et al. $1994 \mathrm{a}, \mathrm{b})$, indicating that both species of turtles go through the transition from a pelagic to a coastal lifestyle at a similar size in the Pacific and Indian Oceans. Although maximum sizes of turtles were similar in both locations, there were marked differences in the size structure of populations in Moreton Bay and Shark Bay. Size distributions were skewed towards larger turtles in Shark Bay relative to Queensland (see Limpus et al. 1994a,b). Our data likely underestimate the differences for green turtles; in Shark Bay, shallow banks are often quite narrow, and large green turtles frequently congregate in deeper areas (4 to $4.5 \mathrm{~m}$ ) of the banks where they have easy access to deep (8 to $10 \mathrm{~m}$ ) waters into which they can escape (authors' unpubl. data). The frequency of the smallest green turtle size classes (<55 cm CCL) may be slightly underestimated, since these turtles were captured primarily in shallow mangrove-lined habitats that were not sampled as frequently as offshore banks. The size distribution of sampled loggerhead turtles, however, is likely to be very close to that found in the population, as there are no differences in size among habitats and loggerheads of all size classes are relatively easy to capture.

We suggest that the difference in the size structures of green turtle populations in Moreton Bay and Shark Bay is likely due to the heavy exploitation of turtles in the former area, where the relative lack of large turtles is consistent with a population rebounding from a relatively recent decline (1950s; Limpus et al. 1994a). Indeed, assessments of size structure among lessexploited green turtle populations in the Great Barrier Reef region of Queensland also have revealed a higher proportion of large individuals than in Moreton Bay (Limpus and Reed 1985, Limpus et al. 1994a). Unlike green turtles, loggerhead turtles have not been subjected to substantial harvests in eastern Australia (Limpus et al. 1994a,b). However, the loggerhead population in Shark Bay is skewed towards larger individuals when compared to both Moreton Bay (Limpus et al. 1994b) and the southern Great Barrier Reef Marine Park (Limpus \& Limpus 2003), but to a lesser extent than green turtles. The reasons for these differences in population size structure remain unclear, but differential levels of human influence (aside from harvest) may still be responsible.

Differences in the proportion of large turtles in a population has substantial implications for the reproductive potential of the population, as larger body size is positively correlated with fecundity and other reproductive parameters (Van Buskirk \& Crowder 1994). It is likely that predation by tiger sharks is greatest on smaller turtles, while human-inflicted mortality would be centered on larger individuals. Under prolonged periods of different mortality regimes, populations would be expected to diverge in their life-history characteristics, including smaller size and younger age at maturity for individuals in populations with high mortality rates at larger sizes (e.g. Grift et al. 2003, Hutchings \& Reynolds 2004).

Within the Shark Bay foraging ground, loggerhead turtle sizes did not vary significantly with depth, but there was a general shift in habitat use within capture areas for green turtles as they reached larger sizes. The smallest size classes of green turtles $(<50 \mathrm{~cm}$ CCL) were occasionally seen and captured on offshore seagrass banks, but were much more abundant on nearshore sand flats and near or in tidal creeks lined with mangroves. Because these shallow mangrovelined habitats were sampled less often than other habitats, we likely have underestimated the tendency to select such areas by small turtles. Furthermore, no green turtles in this size class were observed in 3 yr of conducting transects in deep habitats (e.g. Heithaus 2001, Heithaus et al. 2002b). In general, the use of shallow nearshore habitats by sea turtles is probably driven largely by predation risk. Small green turtles are sometimes found whole in the stomachs of tiger sharks (Simpfendorfer et al. 2001, M. R. Heithaus pers. obs.), and offshore seagrass banks are a preferred habitat of tiger sharks in the study area (Heithaus et al. $2002 b)$. Shallow nearshore waters would provide a refuge from predation because they are difficult for large tiger sharks to access, and their maneuverability would be less than that of juvenile green turtles (e.g. Heithaus et al. 2002a). Spatial variation in the size of green turtles captured has also been observed in Moreton Bay, where larger turtles $(>80 \mathrm{~cm})$ were rarely found within the inner drainages used by smaller turtles. The reason for this spatial variation in Moreton Bay remains unclear, and the role of predation risk is unknown (Limpus et al. 1994b). While large sharks, including tiger sharks, occur in Moreton Bay (Corkeron et al. 1987), no wounds attributed to sharks were recorded on green turtles by Limpus et al. (1994b). However, the lack of predator-inflicted wounds may be due to effective anti-predator behavior (Heithaus et al. 2002a). 
Green turtles, and especially unclassed individuals, were rarely recaptured, which could indicate a low degree of site fidelity. Movements of instrumented green turtles (e.g. Heithaus et al. 2002c), however, suggest that the low recapture rate of green turtles is likely due to high population density rather than most individuals leaving the study area; 24 to $72 \mathrm{~h}$ after deployment, instruments were usually recovered within $1 \mathrm{~km}$ of the deployment location (authors' unpubl. data). Recaptured green turtles moved relatively short distances-only an average of $600 \mathrm{~m}-$ despite the availability of suitable habitat at greater distances. Such fidelity for specific foraging locations is common in green turtles on their feeding grounds throughout their range (e.g. Bjorndal 1980, Brill et al. 1995). For example, most green turtles in Moreton Bay were recaptured within specific feeding locations, and displaced turtles returned to the location of their initial capture (Limpus et al. 1994a). However, off the coast of Brazil and in the Gulf of California, green turtles may be highly resident or exhibit very large home ranges (Seminoff et al. 2002, Godley et al. 2003).

The high recapture rates of loggerhead turtles suggest a high degree of site fidelity to small areas within the Eastern Gulf of Shark Bay, a trend common for this species on feeding grounds (e.g. Limpus et al. 1994b, Avens et al. 2003, Limpus \& Limpus 2003). Few of the loggerhead turtles recaptured in Shark Bay had made substantial moves away from the location of initial capture, although some individuals moved $>10 \mathrm{~km}$, primarily along a relatively thin strip of sand-bottom habitat near shore.

There were seasonal changes in the average condition of green turtles, but none in loggerhead turtles. Green turtles were generally in worse condition during the austral winter, possibly due to the arrival of postbreeding migrants that had recently traveled long distances. Alternatively, green turtle condition may have declined over winter as a result of lower water temperatures. The lack of seasonal variation in loggerhead turtles may reflect the much shorter distance and energetic cost of migrating to their primary breeding and nesting area, Dirk Hartog Island, which is located $<100 \mathrm{~km}$ from the study site compared to $>500$ to $1000 \mathrm{~km}$ to the presumptive green turtle nesting beaches. Alternatively, loggerhead turtles may possess a superior ability to maintain body condition during periods of low temperature. Interestingly, a much greater proportion of green turtles were in poor condition in Shark Bay $(7.1 \%)$ than in Moreton Bay $(0.4 \%$; Limpus et al. 1994a), a result that would be consistent with populations near and below carrying capacity, respectively (e.g. Bjorndal et al. 2000). Conversely, a lower proportion of loggerhead turtles were in poor condition in Shark Bay (3.1\%) than in Moreton Bay (6.3\%).
Previous studies of shark-inflicted wounds in Shark Bay (Heithaus et al. 2002a) did not include an adequate sample of male green turtles, and did not assess the costs of being injured (sub-lethal effects). Green turtles rarely are injured, while loggerhead turtles, particularly males, bear wounds more frequently. Heithaus et al. (2002a) argued that the species difference reflected differences in the attack rate or susceptibility to predatory attack. They suggested that superior maneuverability and speed made green turtles less vulnerable. We suggest another factor may contribute to species differences in shark attack rates: time spent at the surface. The surface appears to be the most dangerous location within the water column for airbreathing animals that are attacked by sharks, and green turtles may dive in a manner to minimize risk while surfacing (e.g. Strong 1996, Glen et al. 2001, Heithaus \& Frid 2003, Heithaus 2004). Loggerhead turtles were seen at the surface more often than green turtles, suggesting more time spent at the surface and thus greater susceptibility to sharks.

While proximate explanations for sex differences among loggerhead turtles remain unclear, Heithaus et al. (2002a) suggested that males may be more willing to incur risk. Shallow habitats are more dangerous than deep ones due to tiger shark abundance (Heithaus et al. 2002b, Heithaus \& Dill 2002), and loggerhead males were recaptured in shallow habitats much more often than were unclassed turtles. This disparity may represent greater use of shallow habitats by males and greater exposure to sharks. Further studies are needed to determine proximate and ultimate causes of species and sex differences in shark attack rates.

The costs of shark-injury to turtles remain unclear. Turtles that successfully escaped from predation attempts with wounds were just as likely to be recaptured (by us) as those that were uninjured, suggesting that there may not be significant differences in longterm survival of these 2 groups or that injured turtles are more likely to be recaptured than turtles that have not been injured. Also, we detected no significant differences in body condition of injured and uninjured turtles. Since most wounds had healed by the time we recorded them, presumably few attacks had been recent, and the victims had been able to regain the energy reserves that might have been lost during recovery. Given the massive nature of some injuries, it is surprising that these turtles show no obvious differences in survival or body condition. Perhaps sub-lethal costs of injury occur during breeding. Males may be poor competitors for mates, and females may experience reduced reproductive success due to increased energetic demands of nesting when injured or greater difficulty in digging nests with injuries to fore- and/or hind-flippers. Immune responses of freshly wounded 
nesting females suggest that they are able to overcome injuries such that reproductive failure does not occur (Jessop et al. 2003), but the effects of injuries, both recent and old, on fitness have yet to be determined.

Unlike foraging areas in close proximity to dense human populations, where green turtle fibropapilloma may affect up to $92 \%$ of individuals (e.g. George 1997), there was an extremely low occurrence of the disease in Shark Bay green turtles, and none was detected on loggerheads. Frequency of fibropapilloma was lower in Shark Bay than in Moreton Bay (7.9\% of green turtles, $4.4 \%$ of loggerhead turtles), which has a city of almost 1 million people in close proximity (Limpus et al. 1994a,b). Furthermore, in Shark Bay, we observed no obvious damage to turtles caused by interactions with humans, while in Morteton Bay $1.6 \%$ of green turtles and $6.9 \%$ of loggerhead turtles bore wounds from boats and fishing gear (Limpus et al. 1994a,b).

In conclusion, populations of green and loggerhead turtles inhabiting the relatively pristine foraging grounds of Shark Bay exhibit key differences with locations where human impacts are greater. These include fewer anthropogenic injuries and more sharkinflicted injuries in Shark Bay, along with a higher proportion of large individuals, differences in sex ratios and differences in the proportion of turtles in poor condition. These differences suggest that an understanding of turtle populations on foraging grounds based on areas with current or historical human-inflicted mortality and disturbance may result in shifting baselines (Pauly 1995, Baum et al. 2003, Baum \& Meyers 2004). An understanding of turtle populations in relatively pristine habitats, like Shark Bay, are important for establishing baselines that are closer to pre-exploitation values.

Acknowledgements. We thank the Monkey Mia Dolphin Resort for housing and logistical support. CALM, Western Australia provided flipper tags and helped initiate sampling. R. I. T. Prince provided helpful guidance. We thank D. Heithaus, L. Heithaus, J. McLash, C. Genrich, P. Greene, M. Kerford, K.Collins, L. Marshall, J. Wilder, A. Greenley, R. Abernethy, K. Wirsing, V. Alla, R. McPhie, K. Martin, S. Gero, S. Allen, A. Ottensmeyer, S. Smith and R. Whittombe for their assistance. This research was supported in part by the National Geographic Expeditions Council and NSERC Canada grant A6869 to L.M.D. A.F. was supported by NSERC Canada PGS-B scholarship. This is contribution 17 of the Shark Bay Ecosystem Research Project.

\section{LITERATURE CITED}

Aragones LV (2000) A review of the role of the green turtle in tropical seagrass ecosystems. In: Pilcher N, Ismail G (eds) Sea turtles of the Indo-Pacific: research management and conservation. ASEAN Academic Press, London, p 69-85

Aragones LV, Marsh H (2000) Impact of dugong grazing and turtle cropping on tropical seagrass communities. Pac Conserv Biol 5:277-288
Avens L, Braun-McNeill J, Epperly S, Lohmann KJ (2003) Site fidelity and homing behaviour in juvenile loggerhead sea turtles (Caretta caretta). Mar Biol 143:211-220

Baldwin R, Hughes GR, Prince RIT (2003) Loggerhead turtles in the Indian Ocean. In: Bolten AB, Witherington BE (eds) Loggerhead sea turtles. Smithsonian Books, Washington, DC, p 218-232

Baum JK, Myers RA (2004) Shifting baselines and the decline of pelagic sharks in the Gulf of Mexico. Ecol Lett 7: $135-145$

Baum JK, Myers RA, Kehler DG, Worm B, Harley SJ, Doherty PA (2003) Collapse and conservation of shark populations in the northwest Atlantic. Science 299:389-392

Bjorndal KA (1980) Nutrition and grazing behavior of the green turtle Chelonia mydas. Mar Biol 56:147-154

Bjorndal KA (1997) Foraging ecology and nutrition of sea turtles. In: Lutz PL, Musick JA (eds) The biology of sea urtles. CRC Press, Boca Raton, FL, p 199-231

Bjorndal KA (2003) Roles of loggerhead sea turtles in marine ecoystems. In: Bolten AB, Witherington BE (eds) Loggerhead sea turtles. Smithsonian Books, Washington, DC, p 235-254

Bjorndal KA, Jackson JBC (2003) Roles of sea turtles in marine ecosystems: reconstructing the past. In: Lutz PL, Musick JA, Wyneken J (eds) The biology of sea turtles, Vol II. CRC Press, Boca Raton, FL, p 259-273

Bjorndal KA, Bolten AB, Chaloupka MY (2000) Green turtle somatic growth model: evidence for density dependence. Ecol Appl 10:269-282

Bjorndal KA, Bolten AB, Chaloupka MY (2003) Survival probability estimates for immature green turtles Chelonia mydas in the Bahamas. Mar Ecol Prog Ser 252:273-281

Brill RW, Balazs GH, Nolland KN, Chang RKC, Sullivan S, George AC (1995) Daily movements, habitat use, and submergence intervals of normal and tumor bearing juvenile green turtles (Chelonia mydas L.) within a foraging area in the Hawaiian islands. J Exp Mar Biol Ecol 185:203-218

Chaloupka MY, Limpus CJ (1998) Modelling green sea turtle survivorship rates. In: Epperly SP, Braun J (eds) Proc 17th Annual Sea Turtle Symp. NOAA Tech Mem NMFS 415: $24-26$

Chaloupka MY, Limpus CJ (2002) Survival probability estimates for the endangered loggerhead sea turtle resident in southern Great Barrier Reef waters. Mar Biol 140: 267-277

Corkeron PJ, Morris RJ, Bryden MM (1987) Interactions between bottlenose dolphins and sharks in Moreton Bay, Queensland. Aquat Mamm 13:109-113

George RH (1997) Health problems and diseases of sea turtles. In: Lutz PL, Musick JA (eds) Biology of sea turtles. CRC Press, Boca Raton, FL, p 363-385

Glen F, Broderick AC, Godley BJ, Metcalfe JD, Hays GC (2001) Dive angles for a green turtle (Chelonia mydas). J Mar Biol Assoc UK 81:683-686

Godley BJ, Lima EHSM, Åkesson S, Broderick AC, Glen F, Godfrey MH, Lushci P, Hays GC (2003) Movement patterns of green turtles in Brazilian coastal waters described by satellite tracking and flipper tagging. Mar Ecol Prog Ser 253:279-288

Grift RE, Rijnsdorp AD, Barot S, Heimo M, Dieckmann U (2003) Fisheries-induced trends in reaction norms for maturation in North Sea plaice. Mar Ecol Prog Ser 257: $247-257$

Heithaus MR (2001) The biology of tiger sharks (Galeocerdo cuvier) in Shark Bay, Western Australia: sex ratio, size distribution, diet, and seasonal changes in catch rates. Environ Biol Fish 61:25-36 
Heithaus MR (2004) Predator-prey interactions. In: Carrier JC, Musick JA, Heithaus MR (eds) The biology of sharks and their relatives. CRC Press, Boca Raton, FL, p 487-521

Heithaus MR, Dill LM (2002) Food availability and tiger shark predation risk influence bottlenose dolphin habitat use. Ecology 83:480-491

Heithaus MR, Frid A (2003) Optimal diving under the risk of predation. J Theor Biol 223:79-92

Heithaus MR, Frid A, Dill LM (2002a) Species and sex-class differences in shark-inflicted injury frequencies, escape ability, and habitat use of green and loggerhead turtles. Mar Biol 40:229-236

Heithaus MR, Dill LM, Marshall GJ, Buhleier BM (2002b) Habitat use and foraging behavior of tiger sharks (Galeocerdo cuvier) in a seagrass ecosystem. Mar Biol 140: $237-248$

Heithaus MR, McLash JM, Frid A, Dill LM, Marshall GJ (2002c) Novel insights into the behavior of sea turtles from animal-borne cameras. J Mar Biol Assoc UK 82:1049-1050

Hutchings JA, Reynolds JD (2004) Marine fish population collapses: consequences for recovery and extinction risk. Bioscience 54:297-309

Jackson JBC (1997) Reefs since Columbus. Coral Reefs 16:S23-S33

Jessop T, Summer J, Lance V, Limpus C (2003) Reproduction in the shark-attacked sea turtles is supported by stressreduction mechanisms. Proc R Soc Lond B 271:91-94

Lewison RL, Freeman SL, Crowder LB (2004) Quantifying the effects of fisheries on threatened species: the impact of pelagic longlines on loggerhead and leatherback sea turtles. Ecol Lett 7:221-231

Limpus CJ (1993) The green turtle, Chelonia mydas, in Queensland: breeding males in the southern Great Barrier Reef. Wildl Res 20:513-523

Limpus CJ, Limpus DJ (2003) Biology of the loggerhead sea turtle in western South Pacific Ocean foraging areas. In: Bolten $\mathrm{AB}$, Witherington $\mathrm{BE}$ (eds) Loggerhead sea turtles. Smithsonian Books, Washington, DC, p 93-113

Editorial responsibility: Otto Kinne (Editor-in-Chief), Oldendorf/Luhe, Germany
Limpus CJ, Reed PC (1985) The green turtle, Chelonia mydas, in Queensland: a preliminary description of the population structure in a coral reef feeding ground. In: Grigg GC, Sine R, Ehmann H (eds) Biology of Australasian frogs and reptiles. Royal Zoological Society of New South Wales, Sydney, p 47-52

Limpus CJ, Couper PJ, Read MA (1994a) The green turtle, Chelonia mydas, in Queensland: population structure in a warm temperate feeding area. Mem Queensl Mus 35: 139-154

Limpus CJ, Couper PJ, Read MA (1994b) The loggerhead turtle, Caretta caretta, in Queensland: population structure in a warm temperate feeding area. Mem Queensl Mus 37: 195-204

Pauly D (1995) Anecdotes and the shifting baseline syndrome of fisheries. Trends Ecol Evol 10:430

Seminoff JA, Resendiz A, Nichols WJ (2002) Home range of green turtles Chelonia mydas at a coastal foraging area in the Gulf of California, Mexico. Mar Ecol Prog Ser 242: 253-265

Simpfendorfer CA, Goodreid AB, McAuley RB (2001) Size, sex, and geographic variation in the diet of the tiger shark (Galeocerdo cuvier) in Western Australian waters. Environ Biol Fish 61:37-46

Strong WR Jr (1996) Shape discrimination and visual predatory tactics in white sharks. In: Klimley AP, Ainley DG (eds) Great white sharks: the biology of Carcharodon carcharias. Academic Press, New York, p 229-240

Thayer GW, Engel DW, Bjorndal KA (1982) Evidence for short-circuiting of the detritus cycle of seagrass beds by the green turtle, Chelonia mydas L. J Exp Mar Biol Ecol 62:173-183

Van Buskirk J, Crowder LB (1994) Life-history variation in marine turtles. Copeia 1994:66-81

Walker DI (1989) Regional studies-seagrass in Shark Bay, the foundation of an ecosystem. In: Larkum AWD, McComb AJ, Shepherd SA (eds) Biology of seagrasses. Elsevier, New York, p 182-210

Submitted: April 20, 2004; Accepted: December 14, 2004 Proofs received from author(s): February 18, 2005 